\title{
PRELIMINARY TEST RESULTS OF THERMAL COMFORT IN A CLASSROOM
}

\section{WSTĘPNE WYNIKI BADAŃ KOMFORTU CIEPLNEGO W SALI LEKCYJNE}

DOI: 10.30540/sae-2019-021

\begin{abstract}
The paper presents the issue of thermal comfort based on the conducted study. First, the definition and importance of thermal comfort was discussed. Then, air parameters were measured and surveys were conducted regarding questions about the assessment of thermal comfort of persons using the room. The list of the subject thermal comfort evaluation tests are illustrated in the diagrams. The impact of gender and BMI on the Predicted Mean Vote PMV were also analyzed. In the next part, results obtained from surveys and according to formulas from the standard were developed, and then compared.
\end{abstract}

Keywords: thermal comfort, indoor air quality, thermal sensations

Streszczenie

W pracy przedstawiono zagadnienie komfortu cieplnego w oparciu o przeprowadzone badanie. Najpierw omówiono definicję i znaczenie komfortu cieplnego. Następnie wykonano pomiary parametrów powietrza oraz przeprowadzono ankiety dotyczace pytań o ocenę komfortu cieplnego osób użytkujacych pomieszczenie. Zestawienia badań oceny komfortu cieplnego zilustrowano na wykresach. Analizie poddano także wplyw ptci i wskaźnika BMI na przewidywana średniq ocenę PMV. $W$ kolejnej części opracowano wyniki otrzymane z ankiet oraz wedlug wzorów z normy, a następnie je porównano.

Słowa kluczowe: komfort cieplny, jakość powietrza w pomieszczeniu, odczucia termiczne

\section{INTRODUCTION}

Thermal comfort is a very important aspect regarding the conditions that should prevail in the room. To achieve thermal comfort, the microclimate of the room is adjusted by changing the thermal conditions. The basic data on the comfort of heat felt by people in different thermal environments are their individual assessments. He strives to achieve satisfaction among people staying in a given place. Unfortunately, this result will never be completely satisfactory for everyone, due to human biological differences [1].

When assessing thermal sensations, thermal comfort scales are used. The PMV (Predicted Mean Vote) indicator is used to describe thermal comfort in confined spaces. Used mainly in air conditioning.

\section{WPROWADZENIE}

Komfort cieplny jest bardzo ważnym aspektem dotyczącym warunków, jakie powinny panować w pomieszczeniu. Aby go uzyskać, reguluje się mikroklimat pomieszczenia, zmieniając warunki cieplne. Podstawowymi danymi na temat komfortu ciepła odczuwalnego przez ludzi znajdujących się w różnych środowiskach cieplnych są ich indywidualne oceny. Dąży on do osiągnięcia zadowolenia wśród ludzi przebywających w danym miejscu. Wynik ten niestety, nigdy nie będzie w pełni satysfakcjonujący dla każdego ze względu na różnice biologiczne człowieka [1].

Przy ocenie odczuć cieplnych stosuje się skale komfortu cieplnego. Wskaźnik PMV (Predicted Mean Vote) jest stosowany $\mathrm{W}$ opisie komfortu cieplnego $\mathrm{W}$ po- 
Describes human thermal sensations, expressed on a seven-level scale of thermal sensations. Bedford's comfort zone includes three middle ratings: ,pleasantly warm”, ,pleasantly” and „pleasantly cool”. However, according to the American ASHRAE standard, there will be four ratings: ,neither too warm”, ,slightly warm”, ,nor too cold” and ,slightly cold” $[2,3,10]$.

The key element of feeling thermal comfort is air temperature. The influence of other important factors on thermal comfort depends on it. The human body is adapted to operate in a wide temperature range, despite the fact that only in a narrow range is the actual thermal comfort felt, providing a pleasant sensation with the sensation of temperature.

The average neutral temperature for people of different ages and sex is about $25-26^{\circ} \mathrm{C}$ at a relative humidity of $50 \%$, low physical activity, as well as clothing with thermal insulation for light clothing $(0.5 \div 0.6$ clo $)$ [1].

Many factors influence comfort or physiologicalpsychological discomfort resulting from the interaction of man and the environment. In the rooms, physical activity performed by people, their clothing and air parameters are important [10]. When a large number of people are in the room, proper temperature control is important. At the optimal air temperature there are statistically 5\% dissatisfied people. An important aspect is to maintain the air temperature in rooms intended for a large group of people [4]. The humidity is also an important factor. Man feels best at humidity in the range of $40 \div 60 \%$. A value of $<30 \%$ causes dry skin and eye irritation. If the relative humidity is $>70 \%$, there is a feeling of skin moisture and discomfort [5].

\section{SUBJECT AND SCOPE OF RESEARCH}

The ENERGIS building is an energy-saving didactic and laboratory building located at Warszawska Street in Kielce, put into use in 2012. The facility is entirely powered by renewable energy sources for the needs of the Faculty of Environmental, Geomatic and Energy Engineering. Combines teaching, research and scientific functions. Photovoltaic and solar panels operate here, heat pumps and air handling units work, and the recovered heat heats utility water. There is also a biomass boiler room. These installations are also didactic positions [6].

The ENERGIS building has a monolithic reinforced concrete structure. The external walls of the building mieszczeniach zamkniętych. Stosowany głównie w klimatyzacji. Opisuje wrażenia cieplne człowieka, wyrażone w siedmiostopniowej skali wrażeń cieplnych. Do strefy komfortu wg Bedforda zalicza się trzy środkowe oceny: „przyjemnie ciepło”, ,przyjemnie” oraz ,przyjemnie chłodno". Natomiast wg amerykańskiej normy ASHRAE będą to cztery oceny: ,ani za ciepło”, ,lekko ciepło”, ,ani za zimno” i „lekko chłodno” $[2,3,10]$.

Kluczowym elementem odczuwania komfortu cieplnego jest temperatura powietrza. Od niej zależy wpływ innych czynników na komfort cieplny. Organizm ludzki jest przystosowany do funkcjonowania w szerokim przedziale temperaturowym, pomimo to tylko o wąskim zakresie jest odczuwalny faktyczny komfort cieplny dostarczający przyjemnych wrażeń związanych z odczuwaniem temperatury. Średnia temperatura obojętna dla ludzi różnego wieku oraz płci wynosi około $25-26^{\circ} \mathrm{C}$ przy wilgotności względnej równej $50 \%$, niskiej aktywności fizycznej, a także ubiorze o izolacyjności cieplnej dla ubioru lekkiego $(0,5 \div 0,6$ clo) [1] .

Wpływ na komfort lub dyskomfort fizjologiczno-psychiczny, wynikający ze wzajemnego oddziaływania człowieka i środowiska, ma wiele czynników. W pomieszczeniach istotne znaczenie ma wykonywana aktywność fizyczna przez ludzi, ich ubiór oraz parametry powietrza [10]. Kiedy w pomieszczeniu przebywa duża liczba osób ważna jest regulacja temperatury. W optymalnej temperaturze powietrza jest statystycznie 5\% osób niezadowolonych. Istotnym aspektem jest utrzymanie temperatury powietrza $\mathrm{w}$ pomieszczeniach przeznaczonych dla dużej grupy ludzi [4]. Ważnym czynnikiem jest też wilgotność powietrza. Człowiek najlepiej czuje się przy wilgotności w przedziale $40 \div 60 \%$. Wartość $<30 \%$ powoduje suchość skóry i podrażnienie oczu. Jeśli wilgotność względna jest $>70 \%$, odczuwalne jest zawilgocenie skóry oraz dyskomfort [5].

\section{PRZEDMIOT I ZAKRES BADAŃ}

Budynek ENERGIS jest energooszczędnym obiektem dydaktyczno-laboratoryjnym znajdującym się przy ulicy Warszawskiej w Kielcach, oddanym do użytku w 2012 roku, w całości jest zasilany z odnawialnych źródeł energii na potrzeby Wydziału Inżynierii Środowiska, Geomatyki i Energetyki. Łączy funkcje dydaktyczne, badawcze i naukowe. Funkcjonują tu fotowoltaika i panele słoneczne, pracują pompy ciepła, centrale wentylacyjne, a odzyskiwane ciepło podgrzewa wodę użytkową. Pracuje również kotłownia na biomasę. Instalacje te są jednocześnie stanowiskami dydaktycznymi [6]. 
are insulated with $25 \mathrm{~cm}$ thick polystyrene, while the internal walls are made of ceramic brick [7].

The study was conducted in October in the ENERGIS building and the outside temperature was $15^{\circ} \mathrm{C}$. During the test, a microclimate meter was used to determine air parameters. The air temperature, black ball temperature and relative humidity were subjected to these tests. At the same time, people in the room completed a survey on the characteristics of the thermal sensations of the microclimate.

\section{TEST RESULTS}

16 people took part in the study. The room temperature was $23.8^{\circ} \mathrm{C}$ and the relative humidity was $36.65 \%$. This allowed for expressing an assessment of thermal comfort and their preferences for the conditions in the room in which they stayed. Based on this study, the opinions of the respondents were compared with the Predicted Average PMV Rating set by the standard for relevant factors. The PMV indicator is an indicator enabling determination of the average rating of a group of people on a seven-level psychophysical rating scale [3]. Figure 1 shows the PMV results obtained according to the standard.
Budynek ENERGIS ma konstrukcję żelbetową monolityczną. Ściany zewnętrzne budynku ocieplone są styropianem o grubości $25 \mathrm{~cm}$, zaś ściany wewnętrzne murowane $\mathrm{z}$ cegły ceramicznej [7].

Badanie zostało przeprowadzone w październiku w budynku ENERGIS, a temperatura zewnętrzna wynosiła $15^{\circ} \mathrm{C}$. W czasie wykonywanego badania został wykorzystany miernik mikroklimatu, aby wyznaczyć parametry powietrza. Tym badaniom podlegała temperatura powietrza, temperatura czarnej kuli oraz wilgotność względna. W tym samym czasie osoby znajdujące się $\mathrm{w}$ pomieszczeniu wypełniali ankietę dotyczącą charakterystyki wrażeń cieplnych mikroklimatu.

\section{WYNIKI BADAŃ}

W badaniu brało udział 16 osób. Temperatura w pomieszczeniu wynosiła $23,8^{\circ} \mathrm{C}$, a wilgotność względna $36,65 \%$. Pozwoliło to na wyrażenie oceny komfortu cieplnego i ich preferencji do warunków panujących w pomieszczeniu, w którym przebywali. Na podstawie tego badania porównano opinie ankietowanych z przewidywaną średnią oceną PMV, określoną przez normę dla odpowiednich czynników. Wskaźnik PMV to wskaźnik umożliwiający określenie średniej oceny grupy osób na siedmiostopniowej, psychofizycznej skali ocen [3]. Na rysunku 1 przedstawiono wyniki PMV uzyskane według normy.

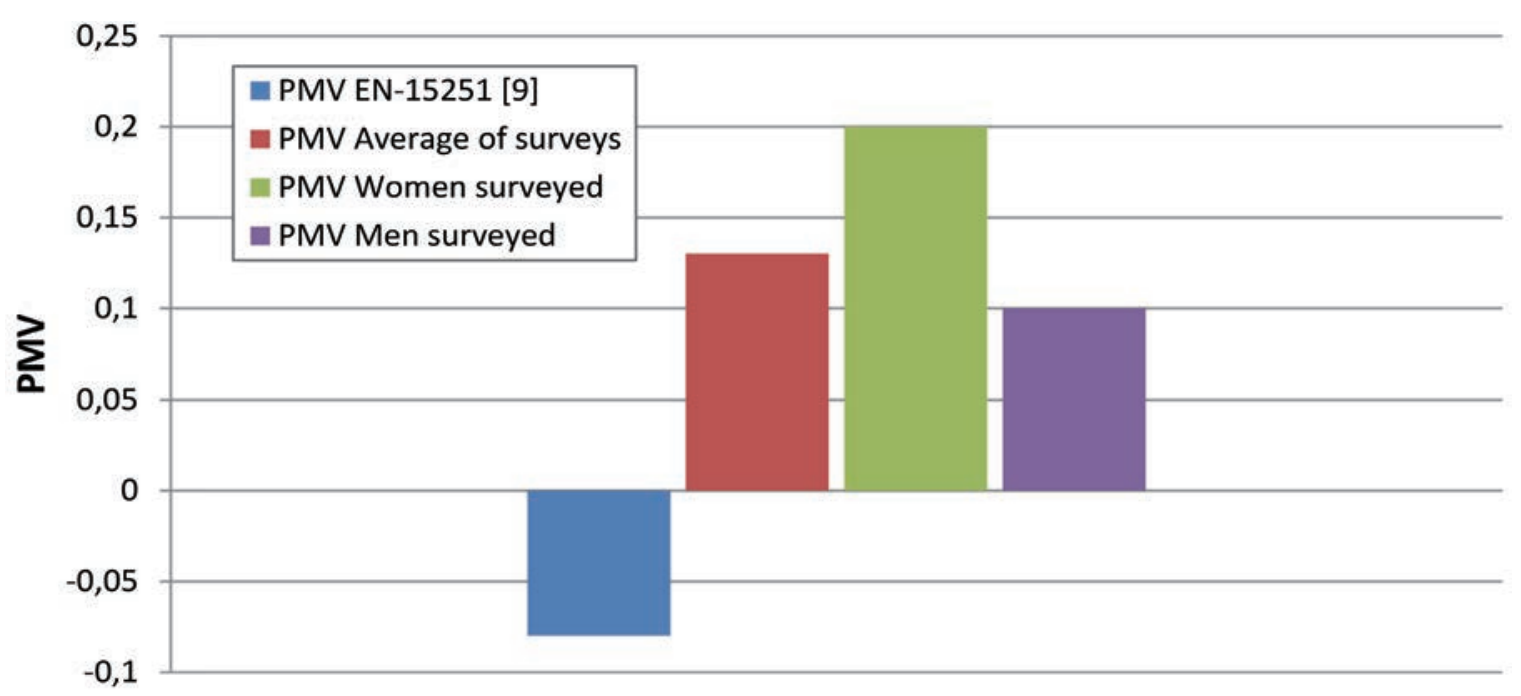

Fig. 1. PMV diagram for the given parameters

Rys. 1. Wykres PMV dla podanych parametrów

Based on a calculator based on the EN-15251 [9] standard, PMV is equal to -0.08 . PMV for 16 people is 0.13 , while for men 0.2 and for women 0.1 . Figure 2 shows PMV responses according to respondents.
Na podstawie kalkulatora skonstruowanego w oparciu o normę EN-15251 [9] PMV jest równe -0,08 PMV dla 16 osób wynosi 0,13 , zaś osobno dla mężczyzn 0,2 , a dla kobiet 0,1 . Na rysunku 2 przedstawiono odpowiedzi PMV według ankietowanych. 


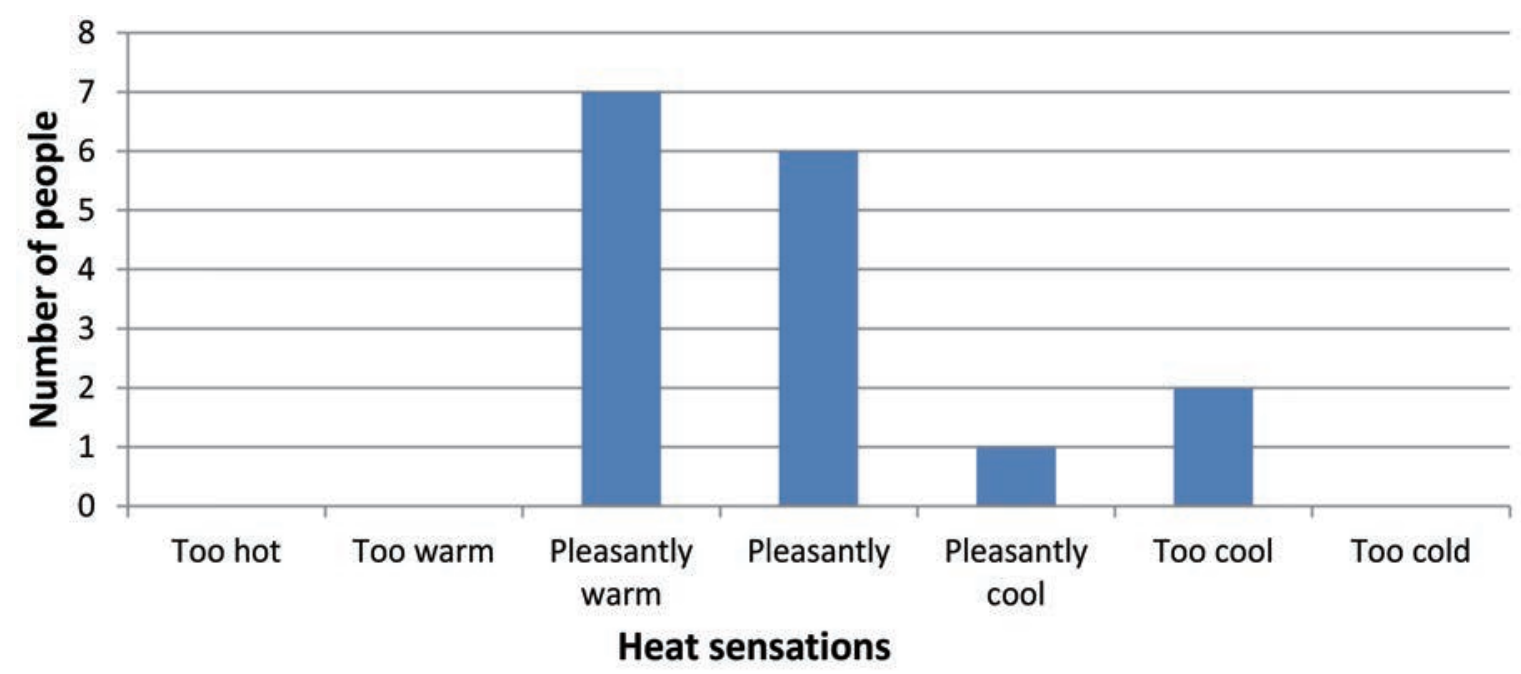

Fig. 2. Thermal feelings according to respondents

Rys. 2. Odczucia termiczne wedtug ankietowanych

6 people feel thermal comfort, 7 people are pleasantly warm, 1 person says it is pleasantly cool, while 2 people are dissatisfied with the prevailing conditions. The calculated PMV value based on the opinions of respondents is 0.13 . Figure 3 shows the temperature rating.
6 osób odczuwa komfort cieplny, 7 osobom jest przyjemnie ciepło, 1 osoba twierdzi, że jest przyjemnie chłodno, natomiast 2 osoby są niezadowolone z panujących warunków. Wyliczona wartość PMV na podstawie opinii ankietowanych wynosi 0,13 . Rysunek 3 przedstawia ocenę temperatury.

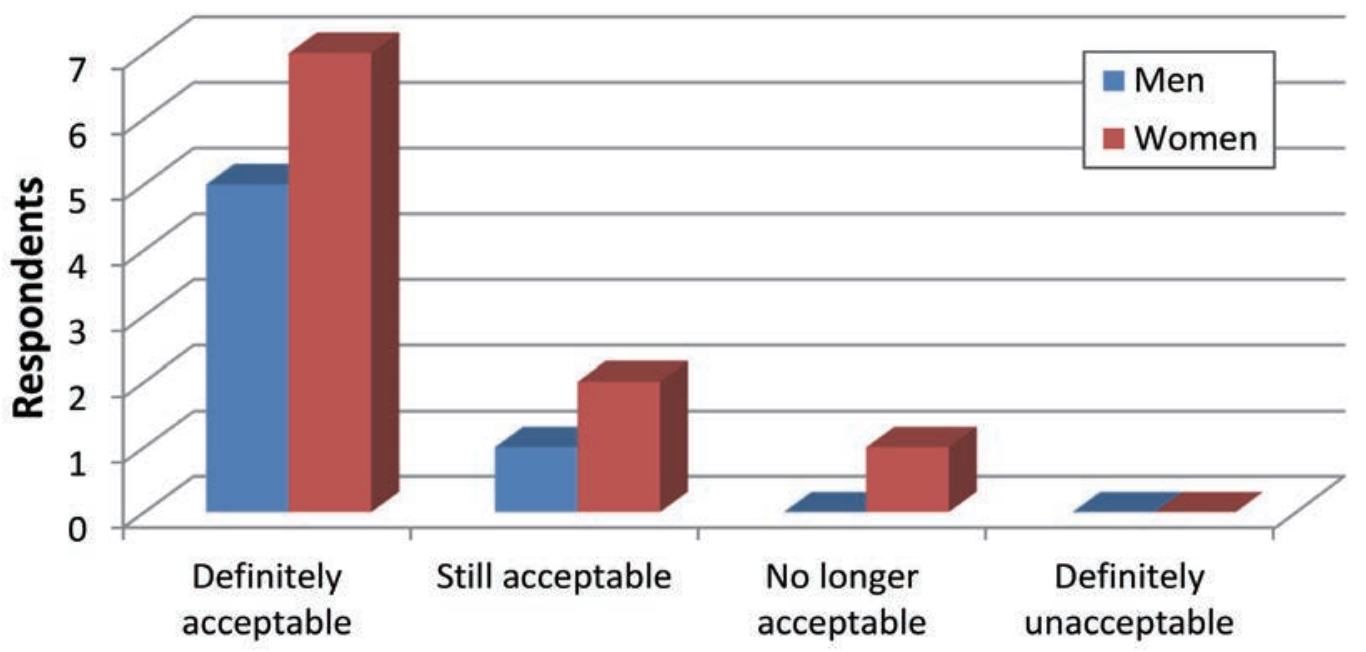

Environmental assessment

Fig. 3. Graph of air temperature assessment by respondents Rys. 3. Wykres oceny temperatury powietrza przez ankietowanych

Figure 3 shows that $75 \%$ of all respondents correspond to indoor conditions, $18.75 \%$ believe that the air temperature is still acceptable. Only $6.25 \%$ of respondents believe that the air temperature is unacceptable.

The Figure 4 is shows relationship between air temperature and individual preferences.
$\mathrm{Z}$ rysunku 3 wynika, że 75\% wszystkich ankietowanych odpowiadają warunki wewnątrz pomieszczenia, 18,75\% uważa, że temperatura powietrza jest jeszcze do przyjęcia. Tylko $6,25 \%$ ankietowanych uważa, że temperatura powietrza już nie jest do przyjęcia.

Na rysunku 4 przedstawiono relacje pomiędzy temperaturą powietrza a indywidualnymi preferencji. 


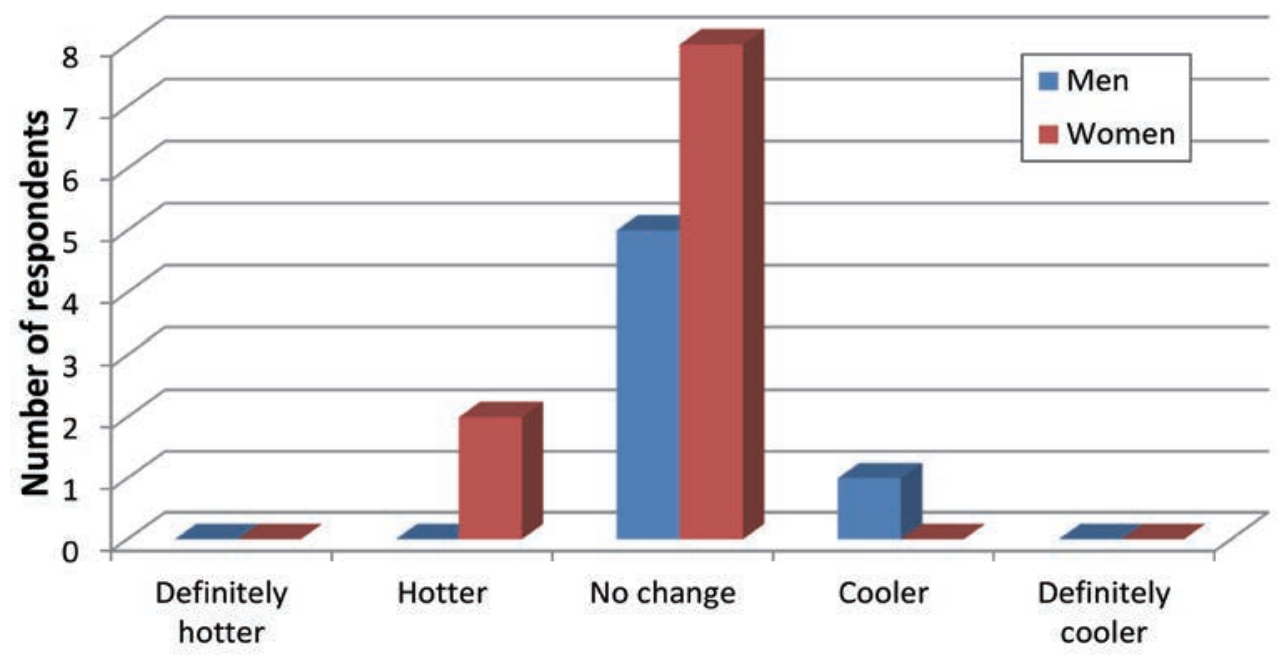

Fig. 4. Graph of air temperature preferences by respondents

Rys. 4. Wykres preferencji temperatury powietrza przez ankietowanych

Only 2 women prefer it to be warmer, which is $12.5 \%$. 13 people want the temperature to be unchanged, i.e. $81.25 \%$ of all respondents. One person would like it to be cooler, which is $6.25 \%$.

Studies have shown that indoor climate conditions are good for people. The PMV value from the opinion of the respondents is 0.13 , which guarantees a feeling of thermal comfort. Parameters calculated using the standard [9] and according to respondents are in the PMV range from $-0.5 \div 0.5$. Then it was checked how BMI and clothing affect the feeling of comfort (Fig. 5).

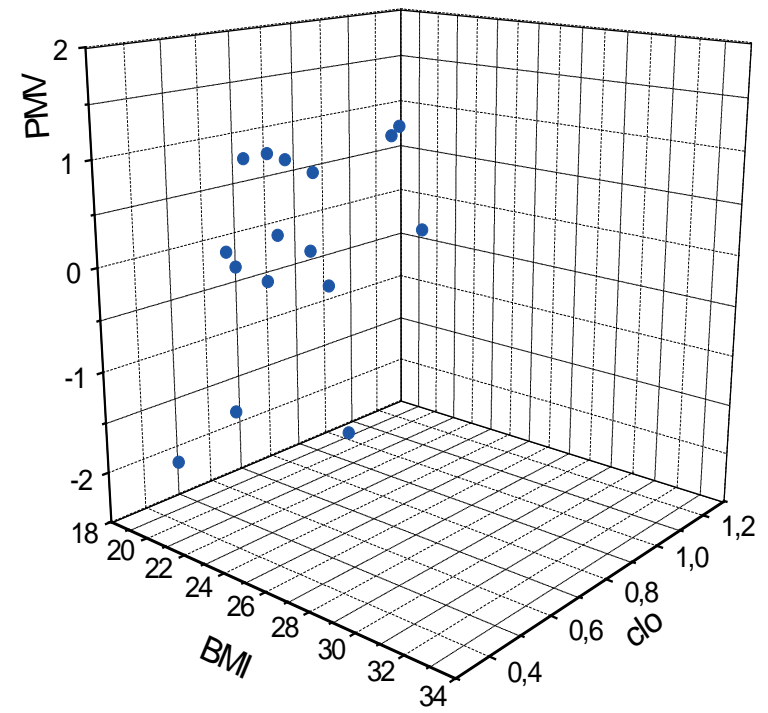

Based on the results obtained, it can be stated that as the body mass index BMI (Body Mass Index)
Jedynie 2 kobiety wolą, aby było cieplej, co stanowi $12,5 \% .13$ osób chce, aby temperatura była bez zmian, czyli $81,25 \%$ wszystkich ankietowanych. Jedna osoba chciałaby, żeby było chłodniej, co stanowi $6,25 \%$.

Badania wykazały, że osobom wewnątrz pomieszczenia odpowiadają warunki klimatu. Wartość PMV $\mathrm{z}$ opinii ankietowanych wynosi 0,13 , co gwarantuje odczucie komfortu cieplnego. Parametry wyliczone za pomocą normy [9], jak i według ankietowanych mieszczą się w zakresie PMV -0.5 $\div 0.5$. Następnie sprawdzono jaki wpływ na odczucie komfortu ma BMI i ubiór (rys. 5).

Fig. 5. Graph of air temperature preferences by respondents Rys. 5. Wykres preferencji temperatury powietrza przez ankietowanych

Na podstawie uzyskanych wyników można stwierdzić, że wraz ze wzrostem wskaźnika masy ciała BMI 
and the clothing's thermal resistance increase, the respondents define the conditions as ,pleasantly warm”. Only 3 people prefer a higher temperature.

\section{SUMMARY AND CONCLUSIONS}

The thermal comfort test took place in the intelligent ENERGIS building in autumn. Based on the study, it can be concluded that the respondents are satisfied with the room temperature. $75 \%$ of respondents are satisfied with the environment in which they are located. Only one woman believes that the air temperature is no longer acceptable, which is $6.25 \%$ of respondents. It can be concluded that women are more prone to temperature sensations. Men in this aspect are usually indifferent. Standard guidelines for the calculation of thermal comfort for the predicted assessment of the average PMV do not differ much from the surveys carried out and are within \pm 0.2 . Thermal comfort tests will be continued in further publications.
(Body Mass Index) i oporu cieplnego odzieży ankietowani określają warunki jako „przyjemnie ciepło”. Tylko 3 osoby wolą temperaturę wyższą.

\section{PODSUMOWANIE I WNIOSKI}

Badanie komfortu cieplnego miało miejsce w inteligentnym budynku ENERGIS w warunkach jesiennych. Na podstawie wykonanego badania można wywnioskować, że ankietowanym odpowiada temperatura $\mathrm{w}$ pomieszczeniu. 75\% badanych jest zadowolonych ze środowiska, w którym się znajdują. Tylko jedna kobieta uważa, że temperatura powietrza już nie jest do przyjęcia, co stanowi $6,25 \%$ ankietowanych. Można uznać, iż kobiety są bardziej podatne na odczucia temperatur. Mężczyźni w tym aspekcie są z reguły obojętni. Wytyczne normowe co do obliczenia komfortu cieplnego dla przewidywanej oceny średniej PMV niewiele się różnią od przeprowadzonych ankiet i mieszczą się w granicy $\pm 0,2$. Badania komfortu cieplnego będą kontynuowane w dalszych publikacjach.

\section{REFERENCES}

[1] Fanger P.O.: Komfort cieplny, tt. doc. dr inż. K. Kostyrko, dr A. Kostyrko, Arkady 1974.

[2] Bedford T.: The warmth factor in Comfort at work. MRC industrial health board. London HMSO 1936.

[3] ASHRAE Standard Thermal Environmental Conditions for Human Occuoancy, 2003.

[4] Śliwowski L.: Mikroklimat wnętrz i komfort cieplny ludzi w pomieszczeniach, Oficyna Wydawnicza Politechniki Wrocławskiej, Wrocław 1999.

[5] PN-EN ISO 7730: 2006 Ergonomics of the thermal environment - Analytical determination and interpretation of thermal comfort Rusing calculation of the PMV and PPD indices and local thermal Comfort criteria.

[6] Website: http://energis.tu.kielce.pl/index.php/krotki_opis_projektu (access 15.10.2019).

[7] Tracz W., Piotrowski J.Z.: Projekt budynku dydaktyczno-laboratoryjnego z tacznikiem wydziału Inżynierii Środowiska Politechniki Świętokrzyskiej w Kielcach, Kielce 2008.

[8] Website: http://comfort.cbe.berkeley.edu/ (access 15.10.2019).

[9] PN-EN 15251: 2006 Indoor environment al input parameters for design and assessment of energy performance of bildings ad dressing indor air quality, thermal environment, lighting and acoustics.

[10] Bartal I., Banhidi Hc. L., Garbai L.: Analysis of the static thermal comfort equation, Energy Buildings, Department of Building Service Engineering and Process Engineering, Budapest University of Technology and Economics, Muegyetem" rkp. 3, Hungary 2012.

\section{Acknowledgments:}

The work was financed by Kielce University of Technology

\section{Podziękowania:}

Praca była finansowana przez Politechnikę Świętokrzyska w Kielcach 